\title{
Promising black locust (Robinia pseudoacacia L.) cultivars in Hungary
}

\author{
Rédei, K. ${ }^{1}$, Keserü, Zs. ${ }^{2}$, Csiha, I. $^{2}$, Rásó, J. ${ }^{2}$ \& Takács, M. ${ }^{1}$ \\ ${ }^{1}$ Faculty of Agricultural and Food Sciences and Environmental Management, University of Debrecen, Debrecen, Hungary \\ ${ }^{2}$ National Agricultural Research and Innovation Centre Forest Research Institute (NARIC), Department of Plantation Forestry, \\ Püspökladány, Hungary, \\ Author for correspondence: Rédei, K. (redei.karoly@gmail.com)
}

\begin{abstract}
Summary: In Hungary, black locust (Robinia pseudoacacia L.) is one of the most important exotic stand-forming tree species, growing mostly under unfavourable ecological conditions. Considering the climate change effects its importance is increasing in many other countries. As a result of a selection programme, several black locust cultivars have been improved for setting up cultivar trials. In the paper four black locust cultivars were evaluated in Central Hungary under arid hydrological and brown forest soil conditions. Significant differences $(\mathrm{P}<5 \%)$ were found in height, DBH, mean tree volume and average stem form value (SFV). At the age of 35 the cultivar 'R.p. Jászkiséri' appeared to be the most promising one for yield production and 'R.p. Zalai' for SFV.
\end{abstract}

Rédei, K., Keserü, Zs., Csiha, I., Rásó, J., Takács, M. (2018): Promising black locust (Robinia pseudoacacia L.) cultivars in Hungary. International Journal of Horticultural Science 24(3-4): 18-20. https://doi.org/10.31421/IJHS/24/3-4./2047

Key words: Robinia pseudoacacia L., clonal approach, growth, yield

\section{Introduction}

Black locust (Robinia pseudoacacia L.) is a species native to North America that has a long tradition of uses as an ornamental, forest tree, street tree, and is also favoured by beekeepers. The tree is naturalised in many parts of the world including Asia, Africa and several countries in Europe. Black locust is an early successional species readily colonising open grounds, but not regenerating in the shade, usually outcompeted by longer living hardwoods in the course of succession.

Since the introduction of black locust into Hungary this tree species has been closely associated with agriculture, and its wood could be utilized for many agricultural and domestic purposes. After World War II its importance changed, because large-scale farms had lower demand for wood and the timber industry was not willing to buy black locust wood. It was necessary to improve the quality of final products of black locust forests to meet the demands of consumers. Therefore, new cultivars had to be produced by selection techniques and had to be introduced into the practical forestry use (Keresztesi, 1988).

The strategy aimed to improve the quality of black locust stands, which were considered to be separate provenances. In the best black locust stands tree groups of shipmast stem form, then plus trees were selected by B. Keresztesi and his colleagues (Keresztesi, 1988). The offsprings of these selected trees were propagated in a vegetative way (root cuttings) and were grouped together into varieties. Thus, varieties are mostly composed of several clones, but there are also some one-clonevarieties.

Propagation of cultivars was first planned by seedlings, but the seed orchards produced small quantities of seed. So, it was necessary to develop techniques for vegetative propagation (with green cuttings, root cuttings and micropropagation) (Rédei et al., 2002).

At present research is being done partly by international cooperation to find the genetic background of quantitative and qualitative features of varieties of several clones. Clone identification markers are determined for this work at protein and DNS levels. The long-term aim is the investigation of the linkage between quantitative features and selected markers, as well as the determination of genetic factors responsible for quantitative features (Rédei et al., 2008).

Besides Hungary, black locust breeding and improvement is undertaken in the United States (Chalupa et al. 1992), Greece (Dini-Papanastasi \& Panetsos, 2000), Germany (Liesebach et al., 2004; Böhm et al., 2011), Slovakia (Chalupa, 1992), Poland (Kraszkiewicz, 2013), Bulgaria, Turkey (Dengiz et al., 2010), India (Sharma, 2000), China (Dunlun et al., 1995) and South Korea (Lee et al., 2007).

\section{Materials and methods}

\section{Study site}

Data used in this study came from a black locust clone trial established in the forest sub-compartment located at Gödöllö $5 \mathrm{G}$, central Hungary $\left(\mathrm{E} 19^{0} 22^{\prime}, \mathrm{N} 47^{0} 36\right.$,) (Figure 1). It has brown forest soil without groundwater influence. The annual precipitation amounts to only $500-550 \mathrm{~mm}$ in some years, of which less than $350 \mathrm{~mm}$ comes in the dry summer period. 


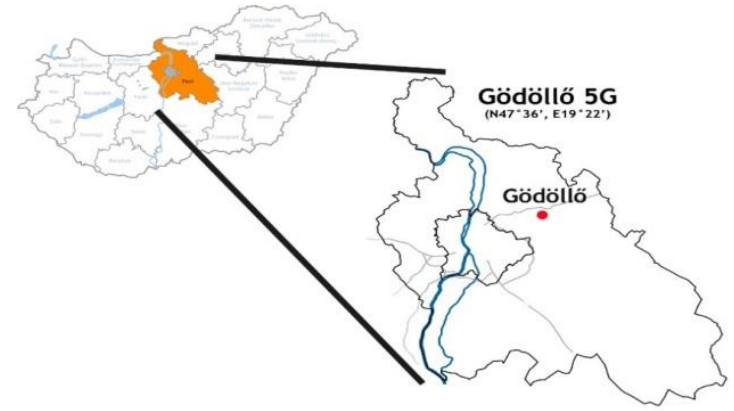

Figure 1. Location of the study site

\section{Materials}

The trial, with three replications was established at a spacing of $2.0 \mathrm{~m} \times 1.0 \mathrm{~m}$. Rooted cuttings of four black locust cultivars, i.e. 'R.p. 'Zalai', R.p. 'Kiskunsági', R.p. 'Nyírségi', R.p. 'Jászkiséri' as well as common black locust as a control were planted. Common black locust plants were produced by seeds. Each treatment corresponds to a plot of 20 by $25 \mathrm{~m}$. A random block was designed where each block included all the different treatments (cultivars) once.

\section{Methods}

The following parameters were measured and calculated at the age of 35 years: number of stems, tree height, DBH (diameter at breast height) over bark, stem volume and mean tree volume. The stem volume was calculated using the following function based on the volume table for black locust $\left(\right.$ Kolozs - Sopp, 2000): $\quad \mathrm{v}=10^{-8} \mathrm{~d}^{2} \mathrm{~h}^{1}(\mathrm{~h} /[\mathrm{h}-1.3])^{2}(-$ $0.6326 \mathrm{dbh}+20.23 \mathrm{~d}+3034)$, where $\mathrm{v}$ is stem volume $\left(\mathrm{m}^{3}\right)$, dbh is diameter at breast height $(\mathrm{cm}), \mathrm{h}$ is tree height $(\mathrm{m})$. The mean tree volume $\left(\bar{v}, \mathrm{~m}^{3}\right.$ per tree) was calculated using the means of stem volume $(\mathrm{h}, \mathrm{dbh})$ for each of the experimental plots (Rédei, 2002).

The stem form classes used by us are as follows at the age of final harvesting: 1) Straight, cylindrical, healthy stems, reaching to the top of the crown. Crooks are tolerated in one dimension only, not more than twice the stem diameter $\left(\mathrm{x}_{1}\right) .2$ ) The stem is straight, forks are tolerated, but only if they are in the uppermost third of the tree. Crooks are tolerated in one dimension only, not more than three times the stem diameter $\left.\left(\mathrm{x}_{2}\right) .3\right)$ The stem is crooked and leaning. Crooks may reach five times the stem diameter in one dimension and minor crookedness in a second dimension is tolerated $\left.\left(x_{3}\right) .4\right)$ Very crooked in more than one dimension, low branching, forked trees with stem defects, broken crown or stem rot $\left(\mathrm{x}_{4}\right)$ (Rédei et al., 2012).

The average stem form value (SFV) was determined on base of the following formula:

$$
\mathrm{SFV}=\frac{x_{1} n_{1}+x_{2} n_{2}+x_{3} n_{3}+x_{4} n_{4}}{n_{1}+n_{2}+n_{3}+n_{4}}
$$

where $x_{1}, x_{2}, x_{3}, x_{4}=$ stem form classes, $n_{1}, n_{2}, n_{3}, n_{4}=$ tree numbers belonging to the single tree quality classes.

The data were analysed by IBM SPSS 22.0 statistical software package. Analysis of variance (one-way ANOVA) was done for height, dbh, mean tree volume and stem form to consider the trial with having completely randomized design.

\section{Results}

Table 1 illustrates the most important stand structure parameters (h, DBH, $\bar{v})$ and the stem form values (SFV) at the age of 35 years and Table 2, illustrates the statistical analysis of them. A comparison of mean height and mean DBH illustrated that the cultivar 'R.p.Jászkiséri' reached the highest value (Figure 2). The same result was obtained in mean tree volume

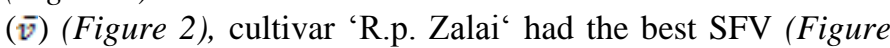

3). $\mathrm{SD}_{5 \%}$ values in case of height $=1.36 \mathrm{~m}$, of $\mathrm{DBH}=1.27 \mathrm{~cm}$, of $\bar{v}=0.066 \mathrm{~m}^{3}$ and of $\mathrm{SFV}=0.179$.

Table 1. Stand characteristics of black locust cultivars at the age of 35 years

\begin{tabular}{|c|c|c|c|c|}
\hline Cultivar name & $\begin{array}{l}\text { Height } \\
\text { (m) }\end{array}$ & $\begin{array}{l}\text { DBH } \\
(\mathrm{cm})\end{array}$ & $\begin{array}{c}\text { Mean tree } \\
\text { volume }(\overline{\bar{v}}) \\
\left(\mathbf{m}^{3}\right)\end{array}$ & $\begin{array}{l}\text { SFV } \\
(1-4)\end{array}$ \\
\hline \multirow{3}{*}{$\begin{array}{l}\text { R.p.'Zalai' } \\
\text { (1) }\end{array}$} & 20.4 & 19.3 & 0.309 & 1.080 \\
\hline & 21.0 & 20.9 & 0.369 & 1.222 \\
\hline & 21.0 & 19.6 & 0.326 & 1.070 \\
\hline \multirow{3}{*}{$\begin{array}{l}\text { R.p.'Kiskunsági' } \\
\text { (2) }\end{array}$} & 21.8 & 23.0 & 0.461 & 1.351 \\
\hline & 23.2 & 23.6 & 0.510 & 1.177 \\
\hline & 22.8 & 22.6 & 0.488 & 1.060 \\
\hline \multirow{3}{*}{$\begin{array}{l}\text { R.p. 'Nyírségi' } \\
\text { (3) }\end{array}$} & 22.0 & 21.6 & 0.410 & 1.205 \\
\hline & 19.4 & 20.6 & 0.341 & 1.140 \\
\hline & 20.4 & 22.0 & 0.401 & 1.145 \\
\hline \multirow{3}{*}{$\begin{array}{c}\text { R.p. 'Jászkiséri' } \\
\text { (4) }\end{array}$} & 23.8 & 26.7 & 0.667 & 1.241 \\
\hline & 23.0 & 26.9 & 0.663 & 1.340 \\
\hline & 23.4 & 26.8 & 0.665 & 1.290 \\
\hline \multirow{3}{*}{$\begin{array}{c}\text { Common black } \\
\text { lotust (control) } \\
\text { (5) }\end{array}$} & 20.7 & 25.6 & 0.551 & 2.370 \\
\hline & 21.7 & 22.4 & 0.439 & 2.623 \\
\hline & 21.3 & 23.4 & 0.470 & 2.485 \\
\hline
\end{tabular}

Table 2. The least significant difference test $\left(\mathrm{LSD}_{0.05}\right)$ of the most important parameters of stand structure at the age of 35 years

\begin{tabular}{|c|c|c|c|c|}
\hline Cultivar name & $\begin{array}{c}\text { Height } \\
\text { (m) }\end{array}$ & $\begin{array}{l}\text { DBH } \\
(\mathrm{cm})\end{array}$ & $\begin{array}{c}\text { Mean tree } \\
\text { volume }(\bar{w}) \\
\left(\mathbf{m}^{3}\right)\end{array}$ & SFV \\
\hline "R. p. Zalai" & $20.8 \mathrm{c}$ & $19.9 \mathrm{~d}$ & $0.335 \mathrm{c}$ & $1.12 b$ \\
\hline $\begin{array}{c}\text { "R.p. } \\
\text { Kiskunsági" }\end{array}$ & $22.6 \mathrm{ab}$ & $23.1 \mathrm{bc}$ & $0.486 b$ & $1.20 \mathrm{~b}$ \\
\hline "R. p. Nyírségi” & $20.6 \mathrm{c}$ & $21.4 \mathrm{~cd}$ & $0.384 \mathrm{c}$ & $1.16 \mathrm{~b}$ \\
\hline "R. p. Jászkiséri" & $23.4 \mathrm{a}$ & $26.8 \mathrm{a}$ & $0.665 \mathrm{a}$ & $1.29 \mathrm{~b}$ \\
\hline $\begin{array}{l}\text { Common black } \\
\text { locust (control) }\end{array}$ & $21.2 \mathrm{bc}$ & $23.8 \mathrm{bc}$ & $0.487 b$ & $2.49 \mathrm{a}$ \\
\hline
\end{tabular}

R. p. - Robinia pseudoacacia L., SFV - stem from value

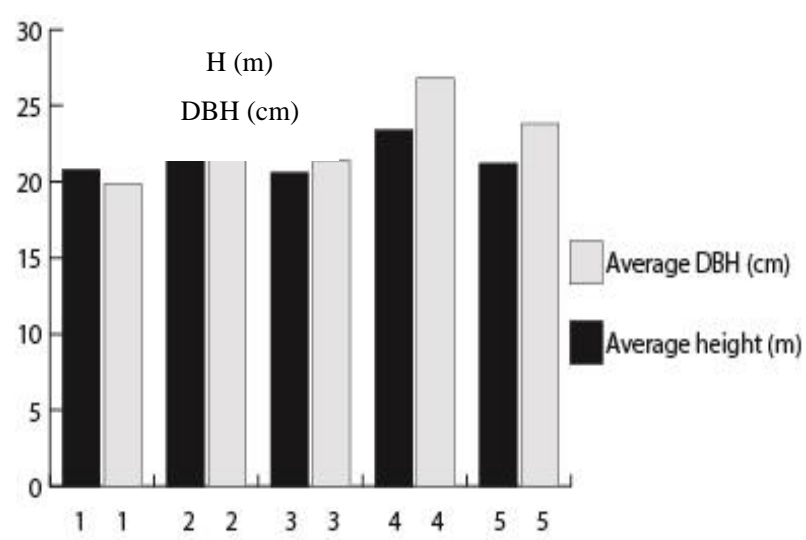

Figure 2. $\mathrm{H}$ and DBH data of 35-year-old black locust cultivars as a mean of plots 


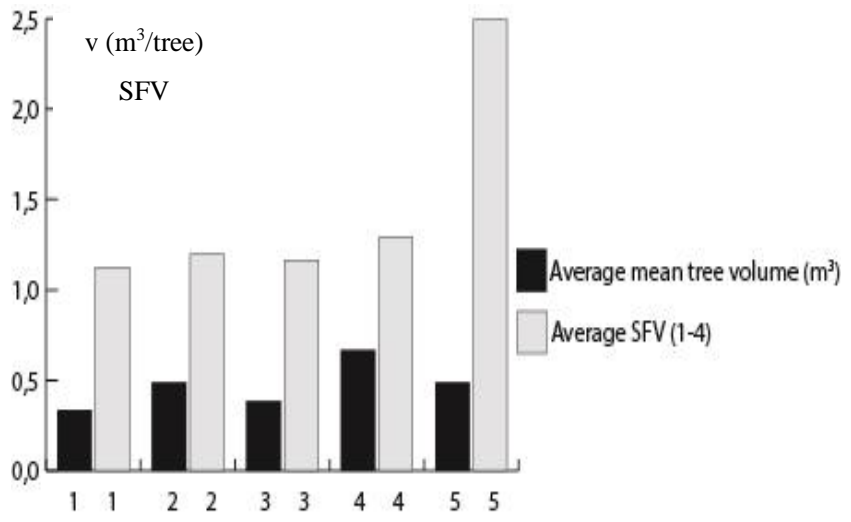

Figure 3. Average mean tree volume (v) and SFV data of 35 -year-old black locust cultivars as a mean of plots

\section{Discussion}

This study leads to the following conclusions: (1) the growth and yield data at the end of the $35^{\text {th }}$ growing season demonstrated that the selected black locust cultivars can be grown successfully under semi-marginal site conditions; (2) vegetative propagation method - rooted cuttings - has proved as a suitable means in the field of black locust clonal selection; (3) by growing selected black locust cultivars it is possible to increase significantly the stem quality and in such a way to increase the ratio of wood material using for industrial purposes (by $25-30 \%$ on average; (4) application of genetic improvement may remove several hindrances to the widespread use of black locust in some, potentially promising countries from black locust growing point of view.

\section{References}

Böhm, Ch., Quinkenstein, A., Freese D. (2011): Yield prediction of young black locust (Robinia pseudoacacia L.) plantation for woody biomass production using allometric relations. Annals of Forest Research 54(2): 215-227.

Bongarten, B.C., Merkle, S.A., Hanover, J.W. (1991): Genetically improved black locust for biomass production in short-rotation plantations. In: Energy from Biomass and Wastes XV (KLASS, D.L. ed.), Institute of Gas Technology. Chicago, IL, 391-409.

Bongarten, B.C., Huber, D.A., Apsley, D.K. (1992): Environmental and genetic influences on short-rotation biomass production of black locust (Robinia pseudoacacia L.) in the Georgia Piedmont. Forest Ecology Management 55: 315331.

Chalupa, V. (1992): Tissue culture propagation of black locust. In: Black locust: Biology, Culture and Utilization (Hanover, J.W., Miller, K. \& Plesko, S. eds.). Michigan State University, East Lansing, 115-125.

Dengiz, O., Gol, C., Sarioglu, F. E., Edis, S. (2010): Parametric approach to land evaluation for forest plantation: A methodological study using GIS model. African Journal of Agricultural Research 5(12): 1482-1496.

Dini-Papanastasi, O., Panetsos, C.P. (2000): Relation between growth and morphological traits and genetic parameters of Robinia pseudoacacia var. monophylla DC in northern Greece. Silvae Genetica 49: 37-44.

Dunlun, Z., Zhenfen, Z., Fangquan, W. (1995): Progress in clonal selection and breeding of black locust (Robinia pseudoacacia L.) In: Forest Tree Improvement in the AsiaPacific Region (Xihuan Shen): China Forestry Publishing House, Beijing, 152-156.

Keresztesi, B. (edit.) (1988): The Black Locust. Budapest. Academic Publishing House, 196.

Kolozs L., Sopp L. (2000): Wood Volume tables. State Forest Service. Ed. Budapest: 271.

Kraszkiewicz, A. (2013): Evaluation of the possibility of energy use black locust (Robinia pseudoacacia L.) dendromass acquired in forest stands growing on clay soils. Journal of Central European Agriculture 14(1): 388-399.

Lee, K. J., Sohn, J. H., Rédei, K., Yun, H. Y. (2007): Selection of Early and Late Flowering Robinia pseudoacacia from Domesticated and Introduced Cultivars in Korea and Prediction of Flowering Period by Accumulated Temperature. Journal of Korean Forest Society 96(2):170-177.

Liesebach, H., Yang M. S., Schneck, V. (2004): Genetic diversity and differentiation in a black locust (Robinia pseudoacacia L.) progeny test. Forest Genetics 11(2): 151-161.

Rédei, K., Osváth-Bujtás, Z., Balla, I. (2002): Clonal approaches to growing black locust (Robinia pseudoacacia) in Hungary: a review. Forestry 75(5): 547-552.

Rédei, K., Osváth-Bujtás, Z., Veperdi, I. (2008): Black Locust (Robinia pseudo-acacia L.) Improvement in Hungary: a Review. Acta Silvatica and Lignaria Hungarica 4: 127-132.

Sharma, K.R. (2000): Variation in wood characteristics of Robinia pseudoacacia L. managed under high density short rotation system. IUFRO World Congress held in Malaysia. 